
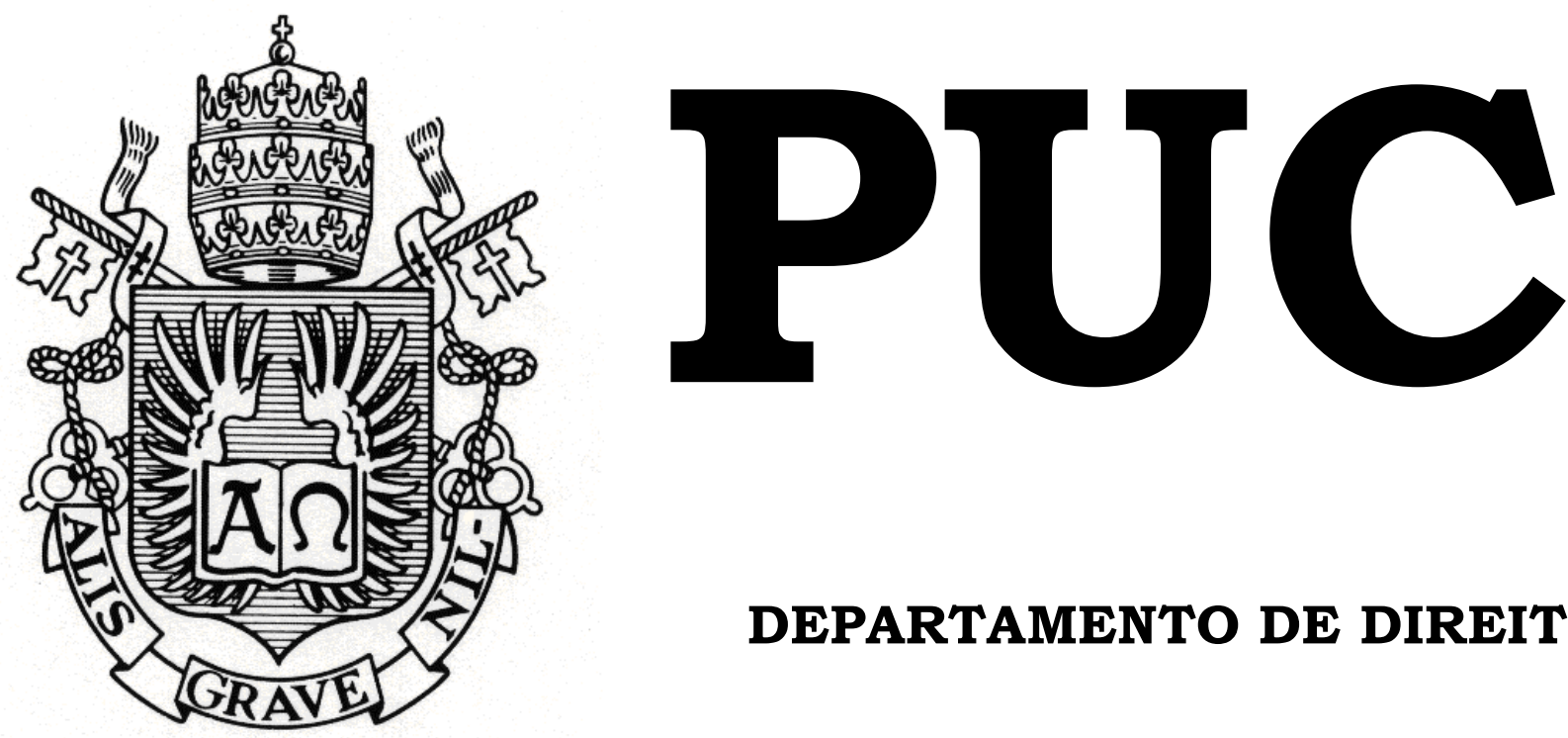

DEPARTAMENTO DE DIREITO

\title{
DA SUSPENSÃO DO EXERCÍCIO DOS DIREITOS DOS ACIONISTAS PELA ASSEMBLÉIA GERAL por
}

MARIANA RODRIGUES MEDITSCH

ORIENTADOR: Julian Fonseca Peña Chediak 2009.2

PONTIFÍCIA UNIVERSIDADE CATÓLICA DO RIO DE JANEIRO

RUA MARQUÊS DE SÃO VICENTE, 225 - CEP 22453-900

RIO DE JANEIRO - BRASIL 


\title{
DA SUSPENSÃO DO EXERCÍCIO DOS DIREITOS DOS ACIONISTAS PELA ASSEMBLÉIA GERAL por
}

MARIANA RODRIGUES MEDITSCH

\begin{abstract}
Monografia apresentada ao Departamento de Direito da Pontificia Universidade

Católica do Rio de Janeiro (PUC - Rio) como requisito parcial para a obtenção do título de Bacharel em Direito.
\end{abstract}

Orientador: Julian Fonseca Peña Chediak

\section{2}




\section{DEDICATÓRIA}

À minha família por todo amor e apoio.

À Camilla pela companhia de estudos durante as madrugadas e amizade. 


\section{AGRADECIMENTOS}

Ao Giovanni Biscardi e Mariana Castello, minha equipe de escritório, que me ensinaram a advocacia empresarial. 


\section{RESUMO}

\section{MEDITSCH, Mariana Rodrigues. DA SUSPENSÃO DO EXERCÍCIO DOS} DIREITOS DOS ACIONISTAS PELA ASSEMBLÉIA GERAL. Monografia (Graduação em Direito) - Pontifícia Universidade Católica do Rio de Janeiro: Rio de Janeiro, 2009.

Trata-se de estudo sobre a suspensão do exercício dos direitos dos acionistas das sociedades anônimas pela assembléia geral, conforme disposto no art. 120 da Lei $\mathrm{n}^{\circ}$ 6.404/76. Este trabalho pretende abordar os seguintes temas: (i) de uma forma geral, os direitos e deveres dos acionistas de uma sociedade anônima; (ii) os direitos passíveis de suspensão nos termos do referido art. 120 da Lei $\mathrm{n}^{\circ}$ 6.404/76; (iii) o detalhamento da ordem do dia da respectiva assembléia geral que deliberar pela referida suspensão do exercício de direitos; (iv) a forma como o exercício dos direitos deverão ser declarados como suspensos; (v) o momento de suspensão do exercício dos direitos, bem como de cessação da referida suspensão; e (v) como atua o controle jurisdicional da deliberação assemblear que declarar o exercício dos direitos de um determinado acionista como suspenso.

\section{Palavras-chave:}

Sociedade Anônima - suspensão - acionistas - direitos - deveres assembléia geral - exercício - privar - essenciais. 


\section{ÍNDICE}

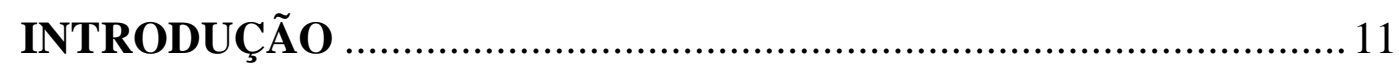

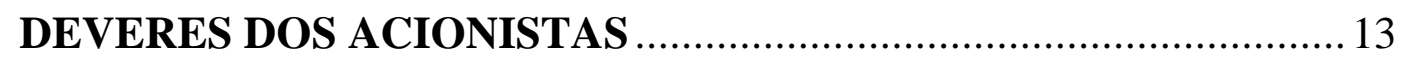

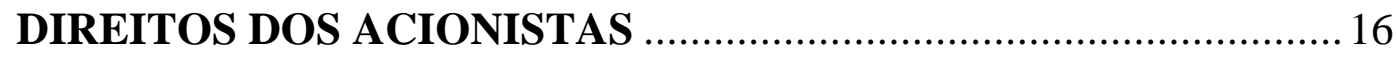

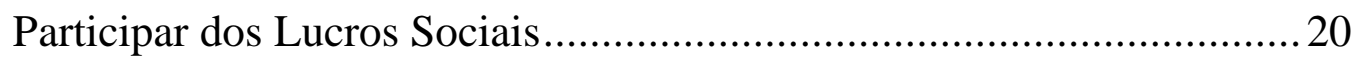

Participar do Acervo da Companhia, em caso de liquidação ....................22

Fiscalizar a Gestão dos Negócios Sociais .............................................22

Preferência para Subscrição de Ações, Partes Beneficiárias Conversíveis

em Ações e Bônus de Subscrição ..........................................................24

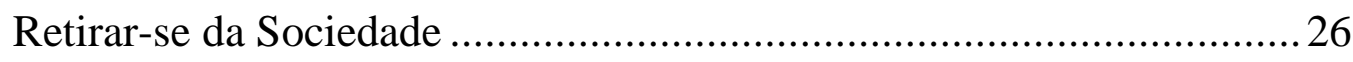

SUSPENSÃO DO EXERCÍCIO DOS DIREITOS................................29

Legitimidade da Assembléia Geral ........................................................29

Obrigações dos Acionistas abrangidas pelo art. 120 ................................35

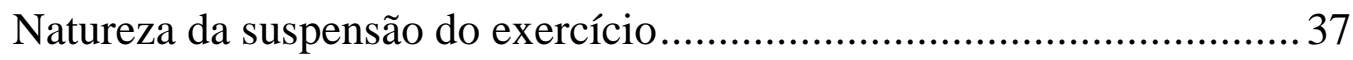

Momento de Suspensão e Momento de Volta e Efeitos ............................38

Direitos suscetíveis de suspensão .......................................................41

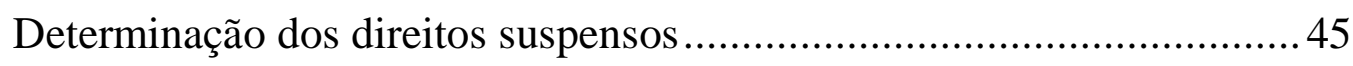

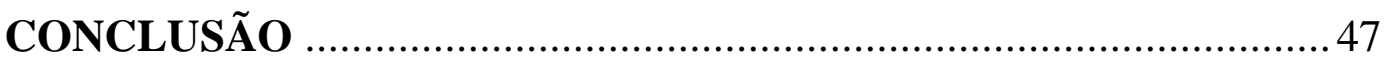

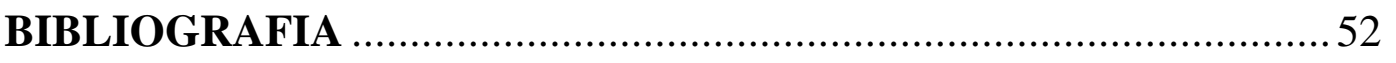




\section{INTRODUÇÃO}

O acionista é conceituado, por José Edwaldo Tavares Borba ${ }^{1}$, como todo aquele, pessoa física ou jurídica, que é titular de ações de uma sociedade anônima.

O acionista, ao subscrever ações de emissão de uma companhia passa a ser considerado como tal e, portanto, titular de direitos e deveres legais e estatutários. Em outras palavras, os direitos e deveres dos acionistas podem ser atribuídos tanto pela legislação societária quanto pelo estatuto social.

O dever mais importante dos acionistas é, sem dúvida, o de integralizar as ações por ele subscritas ou adquiridas, conforme disposto no artigo 106 da Lei ${ }^{\circ}$ 6.404/76, enquanto que os direitos mais importantes são os elencados como essenciais no art. 109 da Lei $\mathrm{n}^{\circ}$ 6.404/76, quais sejam os de participar dos lucros sociais; participar do acervo da companhia, em caso de liquidação; fiscalizar, na forma prevista em lei, a gestão dos negócios sociais; preferência para subscrição de ações, partes beneficiárias conversíveis em ações e bônus de subscrição; e retirar-se da sociedade nos casos previstos legalmente; além do direito de voto que, apesar de não ser essencial, é o direito político mais importante.

O acionista que deixar de cumprir determinados deveres estará sujeito à aplicabilidade de sanção regulada pelo art. 120 da Lei $n^{\circ}$ 6.404/76, qual seja a suspensão do exercício dos direitos dos acionistas pela assembléia geral.

\footnotetext{
${ }^{1}$ BORBA, José Edwaldo Tavares Borba. Direito Societário. 11 ${ }^{\text {a }}$ ed. São Paulo: Renovar, 2008. 572 p.
} 
Tendo em vista que o foco principal do presente trabalho é relacionado ao referido artigo, analisaremos cada elemento utilizado pelo legislador na elaboração de tal dispositivo legal, bem como temas controversos referentes à questões omissas em sua regulação como a necessidade de inclusão da deliberação na ordem do dia constante da convocação enviada aos acionistas da companhia, necessidade de garantir ao mesmo o direito à ampla defesa e ao contraditório, a forma de controle jurisdicional de tal suspensão, eficácia da utilização do art. 120 na defesa dos direitos dos acionistas minoritários para suspensão do exercício de direitos do acionista controlador e demais outros assuntos os quais serão analisados no presente trabalho. 


\section{DEVERES DOS ACIONISTAS}

Como mencionado na Introdução do presente trabalho, além dos direitos, os acionistas possuem deveres para com a companhia. Deveres estes que devem ser cumpridos pelos mesmos em contrapartida aos direitos que a companhia lhe outorga, estes também derivados da sua condição de acionista.

Os deveres impostos aos acionistas são os decorrentes tanto da legislação societária, principalmente da Lei $\mathrm{n}^{\circ}$ 6.404/76, quanto do estatuto social da companhia, o qual poderá atribuir aos acionistas obrigações específicas que não as já atribuídas em lei.

Não serão discutidas neste trabalho as obrigações atribuídas por força do estatuto da companhia, uma vez que as mesmas estão inseridas em um campo abstrato e de infinitas possibilidades, e devem, portanto, serem tratadas conforme o caso aplicável. Assim, a presente análise limita-se aos deveres legais atribuídos aos acionistas.

O dever mais importante deles é, sem dúvida, o de integralizar as ações por ele subscritas ou adquiridas, conforme disposto no artigo 106 da Lei $n^{\circ} 6.404 / 76$ :

"Art. 106. O acionista é obrigado a realizar, nas condições previstas no estatuto ou no boletim de subscrição a prestação correspondente às ações subscritas ou adquiridas.

$\S 1^{\circ}$. Se o estatuto e o boletim forem omissos quanto ao montante da prestação e o prazo ou data do pagamento, caberá aos órgãos da administração efetuar chamada mediante avisos publicados na imprensa, por três vezes, no mínimo, fixando prazo, não inferior a 30 (trinta) dias, para o pagamento.

$\S 2^{\circ}$. O acionista que não fizer o pagamento nas condições previstas no estatuto ou boletim ou na chamada, ficará de pleno direito constituído em mora, sujeitando-se ao pagamento dos juros, da correção monetária e da multa, o que o estatuto determinar, esta não superior a 10\% (dez por cento) do valor da prestação." 
Dispõe ainda a Lei $\mathrm{n}^{\circ}$ 6.404/76 que o acionista que não cumprir com sua obrigação de integralizar as ações correspondentes, passará a ser considerado acionista remisso, nos termos do artigo 107 da Lei n ${ }^{\circ}$ 6.404/76, conforme abaixo:

"Art. 107. Verificada a mora do acionista, a companhia pode, à escolha:

I - promover contra o acionista, e os que com ele forem solidariamente responsáveis (art. 108), processo de execução para cobrar as importâncias devidas, servindo o boletim de subscrição e o aviso de chamada como título extrajudicial nos termos do Código de Processo Civil; ou II - mandar vender as ações em Bolsa de Valores, por conta e risco do acionista.

$\S 1^{\circ}$. Será havida como não escrita, relativamente à companhia, qualquer estipulação do estatuto ou do boletim de subscrição que exclua ou limite o exercício da opção prevista neste artigo, mas o subscritor de boa-fé terá ação, contra os responsáveis pela estipulação, para haver perdas e danos sofridos, sem prejuízo da responsabilidade penal no caso que couber.

$\$ 2^{\circ}$. A venda será feita em leilão especial na Bolsa de Valores do lugar da sede social, ou, se não houver, na mais próxima, depois de publicado aviso, por três vezes, com antecedência mínima de 3 (três) dias. Do produto da venda serão deduzidos as despesas com a operação, se previsto no estatuto, os juros, correção monetária e multa, ficando o saldo à disposição do ex-acionista, na sede da sociedade.

$\S 3^{\circ}$. É facultado à companhia, mesmo após iniciada a cobrança judicial, mandar vender a ação em bolsa de valores; a companhia poderá também promover a cobrança judicial se as ações oferecidas em bolsa não encontrarem tomador, ou se o preço apurado não bastar para pagar os débitos do acionista.

$\S 4^{o}$. Se a companhia não conseguir, por qualquer dos meios previstos neste artigo, a integralização das ações, poderá declará-las caducas e fazer suas entradas realizadas, integralizando-as com lucros ou reservas, exceto a legal; se não tiver lucros e reservas suficientes, terá o prazo de 1 (um) ano para colocar as ações caídas em comisso, findo o qual, não tendo sido encontrado comprador, assembléia geral deliberará sobre a redução do capital em importância correspondente.

Ademais, a Lei no 6.404/76 não dispõe a respeito de outros deveres específicos que sejam atribuídos aos acionistas, mas podemos inferir do texto legal outros direitos decorrentes indiretamente de dispositivos legais, quais sejam os deveres de:

comparecer à assembléia geral; 
(ii) proferir o voto relativo às matérias constantes da ordem do dia da assembléia geral em questão;

(iii) apontar os problemas que a afetam e colaborar para a solução;

(iv) não praticar atos de concorrência para a sociedade; e

(v) lealdade. 


\section{DIREITOS DOS ACIONISTAS}

Além dos deveres atribuídos aos acionistas, conforme mencionado no Capítulo anterior, a lei confere aos acionistas diversos direitos, os quais também podem ser outorgados pelo estatuto social.

Os direitos legais podem ser divididos entre essenciais e modificáveis, enquanto que os direitos estatutários são somente modificáveis, uma vez que os direitos essenciais são os elencados no art. 109 da Lei ${ }^{\circ}$ 6.404/76, conforme transcrito abaixo, enquanto que os modificáveis são todos aqueles que não os elencados no referido artigo.

Defende Arnaldo Rizzardo ${ }^{2}$ que os direitos atribuídos aos acionistas podem ser divididos conforme classificação diversa, entre direitos patrimoniais e direitos instrumentais. Os direitos patrimoniais são os que possuem expressão econômica (como por exemplo o direito de participar dos lucros, direito de participar do acervo líquido da companhia, em caso de liquidação e etc.), enquanto que os direitos instrumentais se referem à participação na companhia, com enfoque na convivência societária (como por exemplo o direito de participar das assembléias gerais, direito de voto, direito de fiscalizar a administração e etc.).

\footnotetext{
"Art. 109. Nem o estatuto social nem a assembléia geral poderão privar o acionista dos direitos de:

I- participar dos lucros sociais;

II - participar do acervo da companhia, em caso de liquidação;

III - Fiscalizar, na forma prevista nesta Lei, a gestão dos negócios sociais;

IV - preferência para subscrição de ações, partes beneficiárias conversíveis em ações e bônus de subscrição, observado o disposto nos arts. 171 e 172;

$V$ - retirar-se da sociedade nos casos previstos nesta Lei.

$\S 1^{\circ}$. As ações de cada classe conferirão iguais direitos aos seus tiulares.
}

\footnotetext{
${ }^{2}$ RIZZARDO, Arnaldo. Direito de Empresa. 2a ed. Rio de Janeiro: Forense, 2007. 1162 p.
} 
$\S 2^{\circ}$. Os meios, processos ou ações que a lei confere ao acionista para assegurar os seus direitos não podem ser elididos pelo estatuto ou pela assembléia geral.

$\S 3^{\circ}$. O estatuto da sociedade pode estabelecer que as divergências entre os acionistas controladores e os acionistas minoritários, poderão ser solucionadas mediante arbitragem, nos termos em que especificar."

Analisaremos, individualmente, cada um dos direitos elencados no art. 109 da Lei $n^{\circ}$ 6.404/76, os quais, de acordo com José Marcelo Martins Proença ${ }^{3}$, tratam-se de direitos inderrogáveis, intangíveis, irrenunciáveis e imutáveis, não podendo o estatuto nem a assembléia geral excluir ou reduzir os direitos essenciais dos acionistas.

Vale mencionar, no entanto, que da lista taxativa dos direitos essenciais constante do art. 109 da Lei $n^{\circ}$ 6.404/76, não consta o direito de voto. Em outras palavras, o direito de voto não é direito essencial e, portanto, a assembléia geral e o estatuto podem privar o acionista do mesmo.

Dispõe a Lei $n^{\circ}$ 6.404/76 ainda, em seus arts. 15, 111 e 120 que o direito de voto pode ser suprimido pelo estatuto nas seguintes hipóteses: (i) criação de ações preferenciais sem direito de voto e (ii) acionista em mora perante a companhia.

Ainda com relação ao voto, devemos esclarecer que o mesmo não compreende tão somente um direito, mas também um dever, uma vez que o acionista que possui o direito de voto possui o dever de votar conforme o interesse da companhia e não em prol de interesse próprio.

A legislação societária determina, pois, nos termos do caput do art. 115 da Lei $n^{\circ}$ 6.404/76 transcrito abaixo, que é o interesse da companhia que

\footnotetext{
${ }^{3}$ PROENÇA, José Marcelo Martins. Direitos e Deveres dos Acionistas. In: FINKELSTEIN, Maria Eugênia Reis; PROENÇA, José Marcelo Martins (Coord.). Sociedades Anônimas. Série GV Law. São Paulo: Saraiva, 2007.
} 
deve nortear o voto do acionista. $O$ direito de voto, assim, deve ser exercido ex causa societatis, não devendo configurar um instrumento de realização de interesse pessoal, a intenção legislativa é a de que cada sócio contribua para a formação do interesse social. Frise-se que esse interesse social tem natureza objetiva, uma vez que é explicitado no objeto da companhia e nos seus fins lícitos de lucratividade e de utilidade social ou coletiva. Caso o voto não se traduza no interesse coletivo, instaura-se o conflito de interesses e o abuso do direito de voto. ${ }^{4}$

"Art. 115. O acionista deve exercer o direito de voto no interesse da companhia; considerar-se á abusivo o voto exercido com o fim de causar dano à companhia ou a outros acionistas, ou de obter para si ou para outrem, vantagem a que não faz jus e de que resulte, ou possa resultar, prejuízo para a companhia ou para outros acionistas."

Adicionalmente, conforme mencionado no dispositivo legal acima, o voto abusivo é o voto proferido por acionista que possua o dolo de causar dano à companhia ou aos demais acionistas. Enquanto que o voto conflitante é o voto proferido por acionista em prol de interesse pessoal, este incompatível com o interesse social. Em ambos os caso, é cabível a propositura de ação de responsabilidade civil contra o acionista que proferir voto abusivo ou conflitante.

Além dos direitos especificados como essenciais nos termos do art. 109 da Lei $n^{\circ}$ 6.404/76, a Lei $n^{\circ}$ 6.404/76 dispõe a respeito de diversos outros direitos, quais sejam, de acordo com Américo Luís Martins da Silva ${ }^{5}$ :

\footnotetext{
${ }^{4}$ PROENÇA, José Marcelo Martins. Direitos e Deveres dos Acionistas. In: FINKELSTEIN, Maria Eugênia Reis; PROENÇA, José Marcelo Martins (Coord.). Sociedades Anônimas. Série GV Law. São Paulo: Saraiva, 2007.

5 SILVA, Américo Luís Martins da Silva. Sociedades Empresarias. 1ª ed. Rio de Janeiro: Forense, 2007. $888 \mathrm{p}$.
} 
(i) Ingressar no edifício e local de realização da assembléia geral, assinando o livro de presença dos acionistas;

(ii) Tomar parte na assembléia geral, discutindo a matéria da ordem do dia, votando as proposições em pauta, elegendo, quando for o caso, os direitos e, nas assembléias gerais ordinárias, os membros do conselho fiscal $e$ respectivos suplente, assinando a ata respectiva;

(iii) Convocar a assembléia geral quando a diretoria retardar por mais de dois meses a convocação, nos casos previstos em lei ou nos estatutos, ou quando representando 5\%, no mínimo do capital votante, se os administradores não atenderem no prazo de 8 dias, a pedido de convocação que apresentarem, devidamente fundamentado, com indicação das matérias a serem tratadas;

(iv) Examinar, no mês antecedente à data marcada para a assembléia geral ordinária, o relatório da administração sobre os negócios sociais e os principais fatos administrativos do exercício social findo, a copia das demonstrações financeiras e o parecer do conselho fiscal ou dos auditores independentes, se houver, lista de acionistas em mora, de que aquela assembléia geral tiver de tomar conhecimento;

(v) Pedir certidões dos assentamentos dos livros sociais e informações $e$ esclarecimentos aos administradores e o auditor independente sobre os negócios sociais;

(vi) Pleitear ao Conselho Fiscal informações sobre matérias de sua competência, quando represente, pelo menos 5\% do capital social;

(vii) Intentar ação anulatória de da constituição da sociedade por ações ou defeitos dos seus atos constitutivos;

(viii) Demandar a anulação das deliberações em assembléia geral ou especial, irregularmente convocada ou instalada, ou violadoras da lei ou dos estatutos, ou eivados de erro, dolo, fraude ou simulação;

(ix) Mover ação civil de reparação de danos contra fundadores e as instituições financeiras que participarem da constituição por subscrição pública, diretores, membros do Conselho Fiscal ou por atos culposos ou dolosos ou infringentes da lei ou do estatuto social, bem como contra os peritos pela avaliação dos bens entrados para o capital social, desde que represente 5\%, pelo menos, do capital social e a ação não for promovida no prazo de 3 (três) meses da deliberação da assembléia geral;

(x) Mover ação que couber contra o liquidante, até 30 (trinta) dias a contar da publicação da ata de assembléia geral para a prestação final das contas;

(xi) Propor ação para dissolução da sociedade, quando provado que ao pode preencher o seu fim, desde que represente $5 \%$ ou mais do capital social;

(xii) Pedir judicialmente a liquidação da sociedade, se os administradores ou a maioria dos acionistas deixarem de promover a liquidação ou a ela se opuserem;

(xiii) Requerer a falência da sociedade, apresentando sua ação.

Vale ressaltar que com relação aos direitos de fiscalização, os mesmos podem ser exercidos pelos acionistas individualmente ou em conjunto com os demais acionistas, conforme previsto na legislação aplicável, e fundam-se na idéia de verificação da legalidade dos atos praticados pelos órgãos de 
administração da companhia, podendo qualquer cerceamento ou impedimento, por ação ou omissão do exercício desses direitos, ser objeto de medida judicial de nulidade do ato ilegal praticado, bem como de reparação por perdas e danos cabíveis.

\section{Participar dos Lucros Sociais}

O direito de participar dos lucros sociais nada mais é do que o direito de o acionista auferir o retorno financeiro do capital inicialmente investido por ele. Constitui parte intrínseca da intenção de um investidor participar em uma determinada sociedade o recebimento de lucros - o acionista investe capital em uma determina sociedade para que, no futuro, possam advir lucros da empresa realizada pela companhia.

Assim, desde que apurado lucro por uma determinada companhia e em um determinado exercício social, a mesma possui a obrigação legal de distribuir dividendos de acordo com o disposto no estatuto social e, no entanto, não inferior a $25 \%$ (vinte e cinco por cento) do lucro líquido da companhia apurado no exercício social respectivo. Caso o estatuto não dispuser a respeito da distribuição dos dividendos, será devido aos sócios 50\% (cinqüenta por cento) do lucro líquido do exercício social correspondente, conforme disposto no art. 202 da Lei $n^{\circ}$ 6.404/76:

\footnotetext{
"Art. 202. Os acionistas têm direito de receber como dividendo obrigatório, em cada exercício, a parcela dos lucros estabelecida no estatuto ou, se este for omisso, a importância determinada de acordo com as seguintes normas:

I - metade do lucro líquido do exercício diminuído ou acrescido dos seguintes valores:

a) importância destinada à constituição da reserva legal (art. 193); e

b) importância destinada à formação da reserva para contingências (art. 195) e reversão da mesma reserva formada em exercícios anteriores;

II - o pagamento do dividendo determinado nos termos do inciso I poderá ser limitado ao montante do lucro líquido do exercício que tiver sido realizado, desde que a diferença seja registrada como reserva de lucros a realizar (art. 197);
} 
III - os lucros registrados na reserva de lucros a realizar, quando realizados e se não tiverem sido absorvidos por prejuízos em exercícios subseqüentes, deverão ser acrescidos ao primeiro dividendo declarado após a realização.

$\S 1^{\circ} \mathrm{O}$ estatuto poderá estabelecer o dividendo como porcentagem do lucro ou do capital social, ou fixar outros critérios para determiná-lo, desde que sejam regulados com precisão e minúcia e não sujeitem os acionistas minoritários ao arbitrio dos órgãos de administração ou da maioria.

$\S 2^{\underline{0}}$ Quando o estatuto for omisso e a assembléia-geral deliberar alterá-lo para introduzir norma sobre a matéria, o dividendo obrigatório não poderá ser inferior a $25 \%$ (vinte e cinco por cento) do lucro líquido ajustado nos termos do inciso I deste artigo.

$\S 3^{o}$ A assembléia-geral pode, desde que não haja oposição de qualquer acionista presente, deliberar a distribuição de dividendo inferior ao obrigatório, nos termos deste artigo, ou a retenção de todo o lucro líquido, nas seguintes sociedades:

I - companhias abertas exclusivamente para a captação de recursos por debêntures não conversíveis em ações;

II - companhias fechadas, exceto nas controladas por companhias abertas que não se enquadrem na condição prevista no inciso I.

$\S 4^{\circ} \mathrm{O}$ dividendo previsto neste artigo não será obrigatório no exercício social em que os órgãos da administração informarem à assembléia-geral ordinária ser ele incompatível com a situação financeira da companhia. $O$ conselho fiscal, se em funcionamento, deverá dar parecer sobre essa informação e, na companhia aberta, seus administradores encaminharão à Comissão de Valores Mobiliários, dentro de 5 (cinco) dias da realização da assembléia-geral, exposição justificativa da informação transmitida à assembléia.

$\S 5^{\circ}$ Os lucros que deixarem de ser distribuídos nos termos do $\S 4^{o}$ serão registrados como reserva especial e, se não absorvidos por prejuízos em exercícios subseqüentes, deverão ser pagos como dividendo assim que o permitir a situação financeira da companhia.

$\S 6^{\circ}$ Os lucros não destinados nos termos dos arts. 193 a 197 deverão ser distribuídos como dividendos."

O fato de o direito de participar nos lucros ser essencial não impede que os acionistas aufiram dividendos de maneira diversa, conforme classe de ações por eles detidas, e conforme existência de prioridade no recebimento dos mesmos, como é o caso das ações preferenciais. Faz-se importante, no entanto, ressalvar que apesar de ser possível a distribuição de dividendos de maneira não igualitária entre as classes de acionistas, não é possível haver diferenças relativas ao recebimento de dividendos entre acionistas titulares de uma mesma classe de ação. 


\section{Participar do Acervo da Companhia, em caso de liquidação}

Caso a companhia seja liquidada, o acionista possui o direito de participar do seu acervo, após realizado o ativo e satisfeito o passivo. Assim, o remanescente será rateado entre os acionistas da companhia liquidada.

Assim como mencionado no item anterior que a participação nos lucros da companhia constitui no retorno financeiro do capital investido, podemos dizer que a participação do acervo da companhia constitui o reembolso do capital investido na companhia.

\section{Fiscalizar a Gestão dos Negócios Sociais}

Considerando que a direção e gestão dos negócios sociais, bem como a representação geral da Companhia são entregues a terceiros - os administradores - a lei atribuiu aos acionistas o direito de fiscalizar a administração da companhia, desde que cumpridos e observados os requisitos determinados em lei.

O direito de fiscalização pode ser exercido de maneira indireta pelos acionistas através de:

(i) verificação dos livros societários arquivados na sede da companhia;

(ii) publicidade dos documentos da administração da companhia (relatório da administração, demonstrações financeiras, parecer dos auditores independentes e etc.), mediante publicação dos mesmos no jornal de grande circulação eleito pela companhia e no Diário Oficial do Estado onde se localiza a sede da companhia; 
(iii) possibilidade de o acionista ou os acionistas que representem pelo menos $5 \%$ (cinco por cento) do capital social solicitarem informações ao Conselho Fiscal; e

(iv) possibilidade de os acionistas convocarem a assembléia geral quando os administradores retardarem na sua convocação.

Assim, podemos sintetizar que o direito de fiscalização dos negócios sociais compreende o poder garantido ao acionista de acompanhar e tomar conhecimento dos negócios e atividades praticados pela companhia através de seus administradores.

Américo Luís Martins da Silva ${ }^{6}$ esclarece que o direito de fiscalização pode ser exercício pelos acionistas das seguintes formas:

(i) Estabelecendo, em seu art. 133 da Lei $n^{\circ}$ 6.404/76, que antes da realização da assembléia geral ordinária, a administração da companhia deve colocar à disposição dos acionistas para consulta (a) o relatório da administração sobre os negócios sociais e os principais fatos administrativos do exercício findo; (b) a cópia das demonstrações financeiras; (c) o parecer dos auditores independentes, se houver; (d) o parecer do Conselho Fiscal, inclusive votos dissidentes, se houver; e (e) demais documentos pertinentes a assuntos incluídos na ordem do dia da assembléia geral ordinária;

(ii) Assegurando o direito de os acionistas que representem, no mínimo, um décimo das ações com direito a voto ou cinco por cento das ações sem direito a voto, pedirem à assembléia geral instalação do Conselho Fiscal, quando o seu funcionamento não for permanente;

(iii) Tornando obrigatória a eleição anual do Conselho Fiscal;

(iv) Ordenando que a companhia remeta cópia do relatório da administração sobre os negócios sociais e os principais fatos administrativos do exercício findo, das demonstrações financeiras, parecer dos auditores independentes (se houver), parecer do Conselho Fiscal, demais documentos pertinentes a assuntos incluídos na ordem do dia ao acionista, que representar 5\% ou mais do capital social, que o pedirem por escrito, com a indicação do endereço completo;

(v) Concedendo a todos os acionistas o ingresso nas assembléias gerais, a fim de tomar as contas dos administradores, examinar, discutir e votar as demonstrações financeiras;

\footnotetext{
${ }^{6}$ SILVA, Américo Luís Martins da Silva. Sociedades Empresarias. $1^{\text {a }}$ ed. Rio de Janeiro: Forense, 2007. 888 p.
} 
(vi) Determinando que o Conselho Fiscal forneça ao acionista ou grupo de acionistas que representem no mínimo $5 \%$ do capital social, sempre que solicitadas, informações sobre matérias de sua competência;

(vii) Assegurando a exibição integral dos livros de escrituração da companhia, quando ordenada judicialmente, mediante requerimento de acionistas que representem $5 \%$ do capital social, para comprovação de atos apontados como violadores da lei ou do estatuto, haja fundada suspeita de graves irregularidades praticadas por qualquer dos órgãos da companhia;

(viii) Outorgando o direito de pedir a dissolução da sociedade por decisão judicial, quando provado que ela não preencha mais seus fins;

(ix) Assegurando o direito de qualquer acionista pedir a convocação da assembléia geral nos casos previstos em lei ou no estatuto, quando os administradores retardarem por mais de 60 dias;

(x) Assegurando o direito de os acionistas que representam 5\% no mínimo do capital social, pedirem devidamente fundamentado, com indicação das matérias a serem tratadas, a convocação da assembléia geral, quando os administradores não atenderem no prazo de 8 (oito) dias;

(xi) Garantindo que os titulares de ações preferenciais sem direito a voto, ou com voto restrito, tenham direito de eleger, em separado, um membro do Conselho Fiscal e respectivo suplente. Igual direito è assegurado aos acionistas minoritários que representem, em conjunto, $10 \%$ ou mais das ações com direito a voto;

(xii) Assegurando o direito de promover ação contra acionistas para restituição de dividendos recebidos de má fé;

(xiii) Assegurando o direito de promover qualquer ação contra a companhia, seja qual for seu fundamento, no prazo de 3 (três) anos."

\section{Preferência para Subscrição de Ações, Partes Beneficiárias Conversíveis em Ações e Bônus de Subscrição}

O direito de preferência para subscrição de ações, partes beneficiárias conversíveis em ações e bônus de subscrição (o "Direito de Preferência") possui como fundamento a manutenção do status quo ante patrimonial dos acionistas, por meio da conservação do percentual do capital social que inicialmente os mesmos possuíam na companhia antes do aumento de capital correspondente.

Em outras palavras, podemos dizer que o Direito de Preferência atribuído em lei aos acionistas da companhia tem como objetivo primordial garantir que aqueles que investiram inicialmente na companhia tenham o 
benefício de nela manter sua participação mediante outorga do Direito de Preferência. Sendo, portanto, atribuído ao próprio acionista a opção de acompanhar o aumento de capital em questão ou ter sua participação diluída.

O Direito de Preferência outorga aos acionistas a preferência para a subscrição de aumento de capital na proporção do número de ações que já sejam titular de emissão da Companhia. Caso o capital social seja dividido em ações de diversas espécies ou classe, o Direito de Preferência deverá ser exercido de acordo com os seguintes procedimentos:

(i) no caso de aumento de capital na mesma proporção da quantidade de ações de todas as espécies e classes existentes, cada acionista poderá exercer o Direito de Preferência sobre ações idênticas as de que o mesmo for titular;

(ii) se as ações emitidas forem de espécies e classes existentes, mas importarem alteração das respectivas proporções no capital social, a preferência será exercida sobre as ações de espécies e classes idênticas às de que forem titulares os acionistas, somente se estendendo às demais se aquelas forem insuficientes para lhes assegurar, no capital aumentado, a mesma proporção que possuíam no capital antes do referido aumento; e

(iii) caso haja emissão de ações de espécie ou classe diversas das existentes, cada acionista exercerá a preferência na proporção da quantidade de ações que for titular, sobre ações de todas as espécies e classes do aumento de capital, nos termos do art. 171 da Lei ${ }^{\circ} 6.404 / 76$. 


\section{Retirar-se da Sociedade}

O direito de retirar-se da companhia é conhecido como direito de recesso ou de retirada. $\mathrm{O}$ mesmo pode ser exercido quando da dissidência de acionistas em determinadas deliberações tomadas em sede de assembléia geral.

O direito de recesso da companhia nada mais é do que um modo de conciliar a vontade da maioria e os interesses da minoria, quando, discordando de uma alteração significativa na estrutura societária, contra ela se tenha manifestado no prazo legal.

Assim, tendo em vista o disposto no parágrafo anterior, apesar de o direito de recesso ser atribuído a todo e qualquer acionista, indistinta e individualmente, podemos dizer que o mesmo constitui instrumento de proteção dos acionistas minoritários contra deliberações tomadas pelos acionistas majoritárias, decisões estas que alterem a estrutura básica da companhia em questão e das quais tais acionistas minoritários sejam dissidentes. Caso contrário, os requisitos necessários para exercício do direito de recesso não estarão presentes.

Ademais, o direito de recesso constitui direito excepcional, em razão de sua natureza ser muito prejudicial à existência da companhia. Dessa forma, a legislação societária, ao garantir o direito de recesso como direito essencial também se preocupou em definir requisitos, ou seja, situações muito específicas, para que o mesmo pudesse ser exercido por acionistas de uma determinada companhia, uma vez que os mesmos poderão sempre retirar-se da sociedade mediante alienação das ações de sua titularidade. 
Conforme já mencionado anteriormente, as deliberações que alterarem a estrutura básica da companhia, ou seja, que possam importar em modificação das diretrizes gerais sociais, bem como dos interesses dos acionistas na participação da companhia, possibilitam o exercício do direito de recesso. Neste caso, o acionista que desejar exercer tal direito, poderá retirar-se da companhia mediante reembolso do valor de suas ações.

São as seguintes deliberações as que possibilitarão o exercício do direito de recesso:

(i) criação de ações preferenciais ou o aumento de classes existentes, em desproporção às demais espécies e classes, salvo se previsto ou autorizado no estatuto social;

(ii) Alteração nas preferências, vantagens e condições de resgate ou amortização de uma ou mais classes de ações preferenciais, ou criação de nova classe mais favorecida. Neste caso, o direito de recesso somente poderá ser exercido pelo titular de ações de espécie ou classe prejudicadas;

(i) Redução do dividendo obrigatório;

(ii) Fusão da companhia, ou sua incorporação em outra. Neste caso, o direito de recesso somente poderá ser exercido pelo titular de ações de espécie ou classe que tenha liquidez e dispersão no mercado, considerando-se haver:

(a) liquidez, quando a espécie, ou classe de ação, ou certificado que a represente, integra índice geral representativo de carteira de valores mobiliários admitido à negociação no mercado de valores mobiliários, no Brasil ou no exterior, definido pela Comissão de Valores Mobiliários; e 
(b) dispersão, quando o acionista controlador, a sociedade controladora ou outras sociedades sob seu controle detiverem menos da metade da espécie ou classe de ação;

(iii) Participação em grupo de sociedades. Neste caso, o direito de recesso somente poderá ser exercido pelo titular de ação de espécie ou classe que tenha liquidez e dispersão, nos termos do disposto no item (ii) acima;

(iv) Mudança do objeto social;

(v) Cisão da companhia. Neste caso, o direito de recesso somente poderá ser exercido se a referida cisão implicar em:

(a) mudança do objeto social, salvo quando o patrimônio cindido for vertido pra sociedade cuja atividade preponderante coincida com a decorrente do objeto social da sociedade cindida;

(b) redução do dividendo obrigatório; ou

(c) participação em grupo de sociedades.

Caso qualquer das deliberações listadas acima seja tomada em sede de assembléia geral, o acionista dissidente da referida deliberação terá o prazo de 30 (trinta) dias, a contar da publicação da respectiva ata da assembléia geral, para exercer o direito de recesso e, conseqüentemente, obter o reembolso do valor das ações por ele detidas, mesmo que o referido acionista tenha se abstido de votar contra a deliberação em questão ou não tenha comparecido à reunião. 


\section{SUSPENSÃO DO EXERCÍCIO DOS DIREITOS}

A suspensão do exercício dos direitos dos acionistas é regulada pelo art. 120 da Lei ${ }^{\circ}$ 6.404/76, o qual dispõe:

“A assembléia geral poderá suspender o exercício dos direitos do acionista que deixar de cumprir obrigação imposta pela lei ou pelo estatuto, cessando a suspensão logo que cumprida a obrigação."

Tendo em vista que o foco principal do presente trabalho é relacionado ao referido artigo, analisaremos cada elemento utilizado pelo legislador na elaboração do referido dispositivo legal, quais sejam: (i) legitimidade da Assembléia Geral; (ii) obrigações dos acionistas abrangidas pelo art. 120; (iii) natureza da suspensão do exercício; (iv) momento de suspensão e momento de volta e efeitos; (v) direitos suscetíveis de suspensão; e (vi) determinação dos direitos suspensos.

\section{Legitimidade da Assembléia Geral}

A competência para determinar a suspensão do exercício dos direitos dos acionistas à atribuída, de maneira, privativa, ao órgão deliberativo supremo de uma companhia - a assembléia geral.

Tal competência não é atribuída somente de forma indireta pela redação do art. 120 da Lei n ${ }^{\circ}$ 6.404/76, como também pela redação do art. 122, $\mathrm{V}$ da mesma lei, o qual elenca as matérias de competência privativa da Assembléia Geral. Assim, é lícito à assembléia geral suspender o exercício dos

direitos dos acionistas que não cumprirem com as suas obrigações sociais. 
No Agravo de Instrumento $\mathrm{n}^{\mathrm{o}}$ 128.396-4/4/GARULHOS da $9^{\mathrm{a}}$ Vara Cível, referente ao Processo $\mathrm{n}^{\circ} 1.849 / 99$, cujo Relator foi Boris Naufumann, foi explicitada tal legitimidade, tema pacífico, da seguinte forma " $o$ art. $120 \mathrm{da}$ Lei das S.A. autoriza a assembléia geral da sociedade anônima suspender o exercício dos direitos do acionista que deixar de cumprir obrigação imposta pela lei ou pelo e estatuto, cessando a suspensão logo que cumprida a obrigação. $O$ exame desse dispositivo com o art. 132 da mesma Lei indica, numa aferição preliminar, que tal matéria somente pode ser deliberada em assembléia geral extraordinária, com expressa inclusão na ordem do dia, dada a gravidade da medida, que retira, ainda que temporariamente, os direitos do acionista. Ora, a deliberação foi tomada em assembléia geral ordinária, e matéria incluída no tópico "outros assuntos" havendo assim, verossimilhança quanto à alegação formulada. E, impedido de votar e de fiscalizar os atos da sociedade, apesar do volume de capital, o risco de dano irreparável é patente, justificado a antecipação parcial dos efeitos da tutela."

Ademais, para que a assembléia geral seja autorizada a determinar a suspensão do exercício de direitos de um determinado acionista, faz-se necessário e imprescindível que seja apresentada prova de descumprimento do dever social por parte do acionista em questão. Em outras palavras, não pode a assembléia geral determinar a suspensão embasada em suspeitas de descumprimento.

Ainda com relação ao tema, é debatido entre doutrinadores se a deliberação de suspensão deve ser precedida de inclusão na ordem do dia constante da convocação enviada aos acionistas da companhia e, caso necessária tal inclusão, em que minúcias o tópico deverá ser descrito. Ou seja, se "suspensão do exercício do direito de acionistas" basta ou se outras informações deverão ser fornecidas, tais como: direitos suscetíveis de 
suspensão, acionista que poderá ter o exercício de seus direitos declarados como suspensos, obrigação social inadimplida e etc.

Modesto Carvalhosa, por exemplo, entende não ser necessária a inclusão na ordem do dia por ser a suspensão matéria de "interesse coletivo" da companhia. Assim, caso tivesse a deliberação que ser necessariamente precedida de inclusão na ordem do dia e a mesma não fosse, estaria deixando a companhia de executar medida de interesse social.

Contrariamente à corrente defendida por Modesto Carvalhosa, muitos outros doutrinadores entendem que, caso não fosse necessária tal inclusão, estar-se-ia atribuindo à assembléia geral um poder muito amplo e discricionário. E, portanto, deve a suspensão de direitos de acionista ser incluída na ordem do dia constante da convocação da assembléia geral que deliberará sobre tal matéria.

Ademais, partindo da premissa, dado que a lei é omissa nesta questão, de que é necessária a inclusão na ordem do dia da deliberação que tratará da suspensão dos direitos, faz-se necessário que o acusado seja identificado (neste caso, o acusado será o acionista teoricamente inadimplente para com suas obrigações sociais, sejam estas legais ou estatutárias), para que o mesmo tome conhecimento a respeito da imputação de inadimplência a que lhe é atribuída, a qual cominará na imposição de pena de suspensão de seus direitos acionários.

Outro motivo pelo qual entendemos ser necessária a identificação do acusado é garantir ao mesmo o direito à ampla defesa e ao contraditório, direitos estes garantidos constitucionalmente, na assembléia geral. Assim, caso o acionista esteja sendo acusado injustamente, poderá apresentar as provas e defesa necessárias para evitar a suspensão do exercício de seus direitos. 
Vale ressaltar que a medida exposta acima garante, inclusive, maior segurança à própria companhia, uma vez que, caso o acionista que tiver o exercício de seus direitos indevidamente suspensos o mesmo será legitimado para propor ação de reparação de perdas e danos em face da companhia para ressarcimento dos prejuízos por ele sofridos em razão de tal suspensão injusta.

Adicionalmente, vale mencionar que, caso a decisão da assembléia geral pela suspensão do exercício de direito do acionista ocorrer com violação da lei ou do estatuto, bem como com abuso de direito ou desvio de poder será ainda cabível recurso ao judiciário contra a deliberação, inclusive com a possibilidade de concessão de tutela antecipada.

Com relação à tutela antecipada mencionada acima, vale mencionar que o TJ SP 8 a Câmara, no Agravo de Instrumento no 361.591.4/4-00, Rel. Des. Joaquim Garcia, j. 15.06.2005 entendeu que devido ao fato de tal deliberação tratar-se de medida irreversível, o art. 273, parágrafo segundo do Código de Processo Civil não admitiria a concessão de tutela antecipada para suspender o direito de voto, a suspensão nesse caso seria somente cabível após dilação probatória e desde que assegurados o contraditório e a ampla defesa ao acionista em questão.

A decisão assemblear, no caso da suspensão do exercício dos direitos é considerada como medida extrajudicial no exercício de autotutela do interesse social. Assim, há a necessidade de ela ser devidamente motivada e fundamentada, sendo vedada, portanto, a suspensão automática de direitos, tudo para que possa o acionista, inconformado com a pena aplicada, pleitear sua anulação no judiciário. 
Conforme exposto acima, devido ao fato de a suspensão do exercício de direitos do acionista inadimplente ser fiscalizada e punida através de medida de autotutela do interesse social, o controle jurisdicional da pena imposta ao acionista - suspensão do exercício dos direitos - será feita post factum, caso proposta ação pelo acionista neste sentido.

Dessa forma, o controle jurisdicional se dará após aplicação da medida de suspensão pela assembléia geral por provocação do acionista cujos direitos foram suspensos. É de extrema relevância que o controle jurisdicional se dê post factum, posto que não seria razoável esperar que uma companhia aguardasse decisão judicial transitada em julgado para que pudesse aplicar penalidade àqueles que não cumprem com suas obrigações sociais.

No caso de o acionista acionar o poder judiciário e obter êxito na demanda, este retornará ao seu status quo ante e deverá ser indenizado pelas perdas e danos decorrentes de tal suspensão indevida.

A deliberação da assembléia geral extraordinária que decidir pela suspensão dos direitos de acionista que discordar da referida deliberação, por ter sido esta indevida, está sujeita à apreciação do poder judiciário, uma vez que é lícito ao acionista propor "ação para anular as deliberações tomadas em assembléia geral ou especial, irregularmente convocada ou instalada, violadoras da lei ou do estatuto, ou eivadas de erro, dolo, fraude ou simulação" que, conforme art. 286 da Lei no 6.404/76 a prescrição é de 2 (dois) anos contados da deliberação para propor sua anulação.

Devemos questionar, no entanto, a eficácia da utilização do art. 120 na defesa dos direitos dos acionistas minoritários para suspensão do exercício de direitos do acionista controlador. 
Os acionistas minoritários, em decorrência da participação por eles detida no capital da companhia, não poderiam por quorum insuficiente suspender o exercício de direitos de um acionista controlador, haja visto que o mesmo votaria de maneira contrária a tal deliberação.

Apesar de o mesmo ser claramente conflitado para votar tal matéria, doutrina e jurisprudência entendem que o art. 115 da Lei $n^{\circ}$ 6.404/76 somente seria aplicado post factum, quando não se enquadrar em qualquer das hipóteses taxativas da lei. Assim, caberia ao acionista controlador votar na matéria para que, posteriormente, os minoritários pleiteassem judicialmente a anulação da deliberação tomada em razão de o controlador ter proferido voto em matéria com conflito de interesses.

Nesse caso ainda, os acionistas minoritários, deverão elaborar como pedido na Ação Anulatória não somente a anulação da deliberação, como também para que o controlador seja declarado judicialmente como impedido para votar em tal matéria quando da realização de nova assembléia geral para deliberar tal assunto.

Para evitar que as companhias estejam à mercê da tutela jurisdicional, que muitos sabem ser muito demorada, muitas companhias incluem no seu estatuto social a seguinte cláusula padrão ${ }^{7}$ :

\begin{abstract}
"Na hipótese de o Acionista Adquirente não cumprir qualquer das obrigações impostas por este artigo, o Conselho de Administração convocará Assembléia Geral Extraordinária, na qual o Acionista Adquirente não poderá votar, para deliberar sobre a suspensão do exercício dos direitos do Acionista Adquirente que não cumpriu qualquer obrigação imposta por este artigo, de acordo com os termos do
\end{abstract}

\footnotetext{
${ }^{7}$ A referida cláusula foi extraída, como exemplo, dos estatutos sociais das seguintes companhias: Natura Cosméticos S.A., Cia Hering e Localiza Rent a Car S.A.
} 
art. 120 da Lei $n^{\circ}$ 6.404/76, sem prejuízo da responsabilização do Acionista Adquirente por perdas e danos causados aos demais acionistas em decorrência do descumprimento das obrigações impostas por este artigo."

A inclusão de tal cláusula beneficia os minoritários quando da necessidade de suspensão do exercício de direitos do controlador, pois assim estaria definido no estatuto da companhia a sua proibição de voto.

\section{Obrigações dos Acionistas abrangidas pelo art. 120}

Discorremos no Capítulo "Deveres dos Acionistas" do presente trabalho a respeito dos deveres atribuídos em lei, os quais devem ser cumpridos pelos mesmos na qualidade de titulares de ações de emissão de uma determinada companhia, como contraprestação aos direitos a ele atribuídos em decorrência de tal participação.

As obrigações estatutárias, conforme já mencionado, não foram tratadas especificamente nesta Monografia, uma vez que variam de acordo com o estatuto social e, portanto, possuem infinita variedade.

As "obrigações" as que se refere o art. 120 não correspondem à totalidade das obrigações descritas anteriormente no presente trabalho. Para que possamos delimitar a que obrigações específicas o art. 120 faz menção, faz-se necessário entendermos a utilização das seguintes expressões: "deixar de cumprir obrigação" e "cessando a suspensão logo que cumprida a obrigação".

A expressão "deixar de cumprir" nos remete à idéia de que tal descumprimento tem que se dar através de uma omissão e não através de um ato comissivo por parte do acionista. Para facilitarmos a compreensão, utilizaremos como exemplo duas obrigações legais impostas aos acionistas, 
quais sejam a de integralizar o capital subscrito e a de proferir voto em prol do interesse social.

Considerando que a obrigação de "integralizar o capital subscrito" é passível de omissão por parte do acionista, ou seja, o mesmo se abstém do ato de integralizar, tal obrigação está inserida no escopo do art. 120. O presente argumento pode ser corroborado pela expressão empregada pelo legislador no sentido de que uma vez cumprida a obrigação e, portanto, superada a omissão do acionista nesse sentido, a suspensão do exercício dos seus direitos deverá cessar.

Ao contrário, a obrigação de proferir voto em prol do interesse social não poder ser descumprida através da modalidade omissiva, mas somente comissiva. Enquanto não proferido qualquer voto, não há que se questionar se o mesmo foi proferido de maneira devida ou não. Ao mesmo tempo, uma vez proferido contrariamente ao prol social, o acionista praticou um ato em descumprimento à obrigação a ele imposta. Nesse caso, não seria possível determinar um momento posterior de "cumprimento" que fizesse com que a suspensão cessasse.

Considerando o acima exposto, podemos delimitar que as obrigações abrangidas pelo art. 120 são somente aquelas que podem originar descumprimento por parte do acionista mediante prática de ato omissivo e não comissivo.

Além da discussão apresentada acima, há divergência doutrinária se as obrigações impostas aos acionistas perante os demais, como por exemplo a de 
realizar oferta pública de ações quando da aquisição do controle acionário ${ }^{8}$, estariam abrangidas pelo art. 120 ou se somente estariam abrangidas as obrigações que os acionistas possuem perante a companhia em si, como por exemplo o de integralizar as ações.

Apesar de haver a referida divergência, me filio à corrente majoritária, a qual entende que a lei, ao não especificar quais obrigações estariam abrangidas pelo art. 120, mas tão somente "obrigação imposta pela lei ou estatuto", abrangeu todas e quaisquer obrigações impostas, passíveis de descumprimento por ato omissivo conforme mencionado acima, independentemente de serem estas assumidas perante a companhia ou perante os demais acionistas. Inclusive, as obrigações assumidas por acionistas perante os demais somente decorrem do fato de os mesmos participarem de uma mesma companhia, estando, portanto, inseridos na mesma realidade social.

Assim, utilizando o exemplo dado acima, caso um determinado acionista controlador não realize oferta pública de ações aos acionistas minoritários quando da aquisição do controle, o mesmo estaria sujeito à suspensão do exercício de seus direitos, assim como em caso de não integralização de ações subscritas.

\section{Natureza da suspensão do exercício}

A suspensão do exercício dos direitos dos acionistas possui natureza objetiva com relação ao inadimplemento da obrigação social e não com subjetivo, com relação ao acionista propriamente dito.

\footnotetext{
${ }^{8}$ Art. 254-A da Lei $\mathrm{n}^{\circ}$ 6.404/76: "A alienação, direta ou indireta, do controle de companhia aberta somente poderá ser contratada sob a condição, suspensiva ou resolutiva, de que o adquirente se obrigue a fazer oferta pública de aquisição das ações com direito a voto de propriedade dos demais acionistas da companhia, de modo a lhes assegurar o preço no mínimo igual a 80\% (oitenta por cento) do valor pago por ação com direito a voto, integrante do bloco de controle.".
} 
Definir a natureza da suspensão tem como conseqüência direta respondermos ao indagamento se quando da transferência das ações cujos diretos delas decorrentes estejam temporariamente suspensos de exercício, a suspensão não mais possuirá efeito de forma que o novo detentor das ações voltasse à faculdade de exercer seus direitos ou se os mesmos permaneceriam suspensos.

Conforme já exposto acima, a natureza da suspensão é objetiva. Logo, o exercício dos direitos estarão plenamente eficazes enquanto o inadimplemento perdurar, independentemente se o acionista remisso transferiu suas ações a terceiros ou não.

Para comprovar o liame objetivo da suspensão, Modesto Carvalhosa ${ }^{9}$ utiliza como melhor exemplo de tal objetividade a questão da mora por acionista remisso na integralização de ações por eles subscritas e não pagas: " $a$ suspensão do exercício dos direitos neste caso, atinge apenas as ações em atraso. Se o acionista inadimplente possui outras ações da companhia já integralizadas ou cuja integralização encontra-se em dia, não pode a suspensão abranger tais ações. Assim, a sanção deliberada pela assembléia geral não alcança subjetivamente o acionista, mas apenas as suas ações em atraso. $O$ acionista permanece no pleno exercício dos seus direitos patrimoniais e pessoais, inclusive de fiscalização e de ação, que lhe advêm da titularidade das demais ações não atingidas pela mora."

\section{Momento de Suspensão e Momento de Volta e Efeitos}

\footnotetext{
${ }^{9}$ CARVAlHOSA, Modesto. Comentários à Lei das Sociedades Anônimas. Vol. II. $4{ }^{\mathrm{a}}$ ed. São Paulo: Saraiva, 2008.
} 
A suspensão do exercício dos direitos dá-se mediante deliberação de acionistas tomada em sede de assembléia geral, conforme explicitado no seguinte trecho do art. 120 da Lei $\mathrm{n}^{\circ}$ 6.404/76: "A assembléia-geral poderá suspender". Assim, a assembléia geral é o único órgão social legitimado para determinar a referida suspensão, conforme já discutido anteriormente.

Ademais, a assembléia geral poderá determinar um prazo para que o acionista, a partir daquela data, cumpra a obrigação inadimplida sob pena de ter o exercício de seus direitos suspensos. Nesse caso, o momento da suspensão dar-se-á quando esgotado o prazo e o acionista não cumprir a obrigação, automaticamente. Vale ressaltar que a suspensão somente será automática nesse caso, pois já foi precedida de uma assembléia geral deliberando nesse sentido. Caso, contrário, tal suspensão não poderia dar-se de forma automática.

Sendo a assembléia omissa, o momento da suspensão para o acionista presente ao conclave dar-se-á no mesmo momento da deliberação que aplicou tal pena. Nesse caso, sendo o direito suspenso o de voto, não poderá o acionista remisso votar nas matérias subseqüentes constantes da ordem do dia da referida assembléia.

Já para o acionista ausente ao conclave a suspensão se iniciará com a publicação da ata da qual conste a respectiva deliberação. Vale mencionar que tal publicação, no Diário Oficial do Estado onde se localiza a sede da companhia e em jornal de grande circulação, é requisito fundamental para a eficácia da suspensão.

Uma vez cumprida a obrigação, perante a qual o acionista encontravase inadimplente, o mesmo recupera de imediato, independentemente de 
qualquer formalidade ou autorização de qualquer órgão social, o exercício dos seus direitos, o qual encontrava-se até então suspenso. Assim, não se faz necessário haver uma assembléia geral para determinar a volta de tal exercício, sendo esta, portanto, automática.

$\mathrm{O}$ art. 120, supramencionado, é claro através da expressão "cessando a suspensão logo que cumprida a obrigação". Assim, não é passível de qualquer questionamento o momento da volta do exercício dos direitos.

Dessa forma, para suspender o exercício dos direitos é necessário haver, previamente, uma deliberação tomada em sede de assembléia geral nesse sentido e, no entanto, para cessar a referida a suspensão, basta que o acionista cumpra com a obrigação e a cessação será automática.

Por fim, vale apenas ressaltar que a suspensão do direito de voto deliberada pela assembléia geral não deverá ser jamais confundida com as hipóteses legais de suspensão ou proibição de direito de voto. No caso das hipóteses legais, a suspensão é automática e não necessita de deliberação, uma vez que já estão previstas de maneira objetiva na lei.

Questão relevante que vale ser ressaltada com relação a este item é o efeito que terá a cessação da suspensão. Assim, cabe mencionar que os efeitos serão ex tunc com relação aos aspectos patrimoniais, retroagindo, portanto à data de suspensão do exercício dos direitos e ex nunc com relação aos aspectos políticos. Nesse sentido, o acionista que teve, por exemplo, o direito de auferir dividendos da companhia suspenso, deverá receber da companhia os valores distribuídos até então aos demais acionistas, mas que foram retidos pela companhia em razão de sua mora junto à mesma. No entanto, não seria plausível discutir se o acionista que teve o exercício do seu direito de voto 
suspenso pudesse retroagir todas as deliberações tomadas no período relevante para que seu voto fosse computado, uma vez que as deliberações foram validamente tomadas e, portanto, não devem ser atingidas como ato jurídico perfeito.

\section{Direitos suscetíveis de suspensão}

É de grande discussão na doutrina se a suspensão do exercício de direitos dos acionistas poderá dar-se com relação aos direitos elencados como essenciais no art. 109 da Lei $n^{\circ}$ 6.404/76. Isto porque apesar de o art. 120 da Lei n ${ }^{\circ}$ 6.404/76 utilizar a palavra "direitos", sem especificar quais destes, o art. 109 da mesma lei dispõe que nem a assembléia geral nem o estatuto poderiam privar o acionista de determinados.

A grande questão gira em torno dos seguintes questionamentos: (i) a palavra "direitos" constante do art. 120 abrange todos e quaisquer direitos ou somente os não essenciais?; e (ii) privar significaria o mesmo que suspender o exercício? Conforme as respostas a tais questionamentos, responderíamos à questão primordial: "Pode o exercício dos direitos essenciais ser suspenso?"

Alguns doutrinadores, filiados a uma corrente minoritária, entendem que é somente admissível a suspensão do exercício dos direitos considerados como "modificáveis", todos aqueles que não elencados como essenciais, com base no argumento de que nem o estatuto social nem a assembléia geral poderiam privar o acionista dos direitos considerados essenciais, e privar o acionista de um direito seria o mesmo que suspender o exercício de um determinado direito. 
Assim, de acordo com tal corrente minoritária, cujos partidários mais ilustres são Gudesteu Pires, Waldemar Martins Ferreira e Fran Martins, o dispositivo do art. 120 deveria ser conjugado com o do art. 109, o qual proíbe a assembléia geral e o estatuto de privar o acionista de qualquer dos direitos intangíveis, ou seja, os essenciais.

Além disso, defende tal corrente que suspender o exercício de direitos importaria no mesmo que privar o acionista de tal direito. Assim, a regra específica do art. 109 seria limitador do dispositivo do art. 120 e, portanto, não poderiam os direitos essenciais ser objeto de suspensão.

Fran Martins argumenta que o dispositivo do art. 109, por ser regra geral, deveria prevalecer sobre o dispositivo do art. 120, no qual não foi realizada qualquer distinção entre os direitos que poderiam ser objeto de suspensão.

Nesse sentido, os direitos essenciais dos acionistas não poderiam ser suspensos pela assembléia geral, referindo-se a lei tão somente aos demais direitos, que não os essenciais.

Adicionalmente, Fran Martins ${ }^{10}$ defende não haver qualquer distinção entre "privar" e "suspender o exercício", uma vez que os efeitos, seja da suspensão ou da privação, serão os mesmos para ao acionista: "o verbo 'privar' tem o caráter de retirar, permitir, sem se referir a tempo, donde não ser admissível argumentar-se que a suspensão é privação em caráter simplesmente temporário, não absoluto. Quem está suspenso na realidade está privado de exercer os direitos de acionista; e a lei tanto não quer que isso

\footnotetext{
${ }^{10}$ MARTINS, Fran. Comentários à Lei das Sociedades Anônimas. Tomo I. Vol. II $2^{\mathrm{a}}$ ed. Rio de Janeiro: Forense, 1982.
} 
aconteça, que estatui, de maneira enfática que 'nem o estatuto social nem a assembléia geral poderão privar o acionista' dos direitos que enumera.".

$\mathrm{O}$ entendimento adotado pelo ilustre doutrinador ainda possui como apoio o argumento de que o disposto no art. 109 constitui-se como regra geral, devendo, portanto, prevalecer sobre o art. 120, uma vez que neste artigo não foi estabelecida qualquer exceção. Assim sendo, os direitos essenciais dos acionistas não podem ser suspensos pela assembléia geral, referindo-se a lei, ao estatuir essa regra, a outros direitos que não aqueles especificamente descritos no art. 109.

Por outro lado, a corrente majoritária interpreta que é admissível a suspensão de todos os direitos do acionista, sejam estes essenciais ou não, que descumpre obrigações previstas em lei ou no estatuto social.

Um dos argumentos apresentados pelos doutrinadores que defendem tal pensamento é o de que o art. 120 apenas autoriza a suspensão do exercício e, assim mesmo, somente até o momento em que o acionista cumprir com tal obrigação inadimplida. Não seria razoável que um determinado acionista tivesse seus direitos essenciais garantidos, sem possibilidade de qualquer suspensão, se não cumpriu para com sua obrigação social, em contrapartida.

Esclarece Roberto Papini que o art. 120, ao dispor quanto à suspensão, não faz qualquer tipo de distinção entre direitos essenciais e direitos sociais, utilizando-se somente da palavra "direitos". Além do mais, segundo o mesmo autor, não seria contra o princípio da eqüidade defender, por exemplo, o direito de o acionista remisso com a integralização de ações por ele subscritas auferir dividendos percebidos pela companhia em função de um capital para cuja formação não concorreu. 
José Edwaldo Tavares Borba também opina que a suspensão deve abranger a totalidade dos direitos e inclusive, "suspender" não significa "privar”, uma vez que cumprida a obrigação a suspensão cessar-se-á. Neste caso, a suspensão atuaria como "medida suasória, destinando-se a estimular o acionista ao cumprimento do dever".

Está claro que o motivo do legislador, ao elaborar a redação do dispositivo do art. 120 não foi o de suprimir, privar o acionista de seus direitos, mas sim de, temporariamente, não exercê-los tendo em vista a sua mora pra com a companhia.

Apesar de constituir uma sanção ao acionista, a suspensão tem como objetivo proteger, primordialmente, os interesses da companhia.

Modesto Carvalhosa, também adotante da corrente majoritária, entende que a lei dispõe a respeito do exercício dos direitos do acionista e não suspensão de direitos ligados à ação. Assim, a suspensão imposta pela assembléia geral poderá atingir todos os direitos assegurados ao acionista pela lei ou pelo estatuto, estando neles inclusos os direitos essenciais. O referido doutrinador rebate ainda o argumento de Waldemar Ferreira, adotante da corrente minoritária, de que "suspender o exercício" seria o mesmo que "privar o acionista de exercitá-los", com base na argumentação de que "suspender" seria por tempo limitado e provisório, com restabelecimento do direito ao final do referido prazo, enquanto que "privar" seria definitivo e irreversível.

$\mathrm{O}$ argumento de Modesto Carvalhosa, o qual rebate Waldemar Ferreira, acolhe sentido quando analisamos ao art. 120 que dispõe, expressamente, ter a suspensão do exercício dos direitos dos acionistas caráter 
temporário - a suspensão cessará tão logo cumprida a obrigação. Ou seja, cumprida a obrigação volta-se, independentemente de qualquer formalidade, os

direitos dos acionistas retorna ao statu quo ante, não possuindo, portanto, qualquer caráter de privação de seus direitos e, conseqüentemente, afronta ao preceito estabelecido no art. 109 da mesma lei.

Tendo em vista o exposto acima, o art. 109 não veda a suspensão de exercício de direitos essenciais e, portanto, o art. 120 autoriza a sua suspensão temporária, nos termos em que dispõe a respeito da mesma.

\section{Determinação dos direitos suspensos}

A assembléia geral que deliberar pela suspensão de exercício de direitos não poderá declará-los suspensos de forma ampla e genérica. Para que tal suspensão se dê de forma regular, faz-se necessário que sejam declarados, com minúcia, os direitos que estão suspensos, devendo os mesmos serem, além de individualizados, relacionados à obrigação descumprida.

Adicionalmente, não poderá tal suspensão dar-se com relação a aspectos subjetivos de acionistas em mora, atingindo parcialmente destes. A suspensão deverá atingir de forma igual todos aqueles acionistas que na mesma situação se encontram com vistas a atingir o princípio da eqüidade e fim social. Caso somente parte dos acionistas que se encontrem na mesma condição seja atingida, a suspensão será nula por representar abuso de direito e de poder dos acionistas que assim deliberaram, cabendo a estes responder pelos prejuízos causados àqueles que foram injustamente discriminados.

A declaração da assembléia geral deverá ainda ser objetiva e nunca subjetiva com relação às ações detidas pelo acionista. Em outras palavras, caso 
o acionista, por exemplo, encontre-se remisso com relação à obrigação de integralizar as ações por ele subscritas, em conjunto com outras ações subscritas e integralizadas, tal acionista remisso permanecerá exercendo livremente os direitos relacionados às ações integralizadas e terá suspensos os direitos relacionados às ações não integralizadas.

Vale mencionar que a deliberação, acima de tudo, ao aplicar a pena respectiva ao acionista, deverá ser devidamente justificada e fundamentada, garantindo ao acionista o seu direito à ampla defesa e ao contraditório, consubstanciados no art. $5^{\circ}$, LV da Constituição Federal.

Modesto Carvalhosa ${ }^{11}$ enumera a respeito da declaração da suspensão: “no direito vigente, a suspensão só poderá ser imposta se direta, clara e especificamente o acionista deixar de cumprir obrigação legal ou estatutária. Trata-se, pois de um vínculo jurídico expresso no diploma legal ou na lei interna da companhia, em virtude do qual o acionista tem, perante a sociedade determinadas obrigações de dar, fazer ou não fazer.".

${ }^{11}$ CARVALHOSA, Modesto. Comentários à Lei das Sociedades Anônimas. Vol. II. $4^{\mathrm{a}}$ ed. São Paulo: Saraiva, 2008. 


\section{CONCLUSÃO}

Diante do exposto no presente trabalho, podemos dizer que os acionistas de uma companhia possuem direitos e deveres a eles atribuídos em decorrência de serem estes detentores de ações de emissão de uma determinada companhia.

O dever mais importante a eles atribuído é o de integralizar as ações subscritas, nada dispondo a lei a respeito de outros deveres específicos. No entanto, pode-se inferir do texto legal outros deveres decorrentes indiretamente de tais dispositivos legais, tais como o de comparecer à assembléia geral; proferir o voto relativo às matérias constantes da ordem do dia da assembléia geral em questão; e não praticar atos de concorrência para a sociedade.

Os acionistas que descumprirem com determinados deveres, aqueles que somente podem originar descumprimento por parte do acionista mediante prática de ato omissivo e não comissivo e que tenham sido assumidos perante a companhia e/ou demais acionistas, estarão sujeitos à aplicabilidade do art. 120 da Lei $n^{\circ} 6.404 / 76$, o qual atribuiu à assembléia geral a legitimidade para deliberar a respeito de tal sanção.

A sanção regulamentada pelo art. 120 é a de suspensão do exercício dos direitos do acionista que deixar de cumprir com dever a ele imposto. Direitos estes que poderão abranger todos e quaisquer, inclusive os elencados em lei como essenciais, devendo ser definido pela assembléia geral os limites da suspensão. 
Uma vez cumprida a obrigação por parte do acionista, a suspensão cessará de imediato.

Caso a suspensão tenha sido declarada indevidamente pela assembléia geral, terá o acionista prejudicado legitimidade processual para realizar o controle jurisdicional do ato, o qual é realizado post factum, e, inclusive, pleitear perdas e danos pelos prejuízos a ele causados em decorrência de tal suspensão.

Relevante é ainda a inclusão de tal matéria na ordem do dia da assembléia geral, cuja convocação deverá ser enviada à totalidade dos acionistas. Assim será garantido ao acionista acusado do descumprimento o direito à ampla defesa e ao contraditório.

Por fim, a suspensão possui natureza objetiva, devendo atingir de forma igual todos aqueles acionistas que na mesma situação se encontram com vistas a atingir o princípio da eqüidade e buscar o melhor interesse social. Interesse esse autotutelado pela companhia nos termos do art. 120 da Lei ${ }^{\circ}$ $6.404 / 76$. 


\section{BIBLIOGRAFIA}

CARVAlHOSA, Modesto. Comentários à Lei das Sociedades Anônimas. Vol. II. $4^{\text {a }}$ ed. São Paulo: Saraiva, 2008.

RIBEIRO, Renato Ventura. Direito de Voto nas Sociedades Anônimas. $1^{\mathrm{a}}$ ed. São Paulo: Quartier Latin, 2009.

OLIVEIRA, Celso Marcelo de. Manual de Direito Empresarial. Vol II. $1^{\mathrm{a}}$ ed. São Paulo: IOB Thomson, 2005.

SIMIONATO, Frederico A. Monte. Tratado de Direito Societário. Vol I. Rio de Janeiro: Forense, 2009.

BORBA, José Edwaldo Tavares Borba. Direito Societário. 11ª ed. São Paulo: Renovar, 2008.

LUCENA, José Waldecy. Das Sociedades Anônimas - Comentários à Lei. Vol I. São Paulo: Renovar, 2009.

RIZZARDO, Arnaldo. Direito de Empresa. $2^{\mathrm{a}}$ ed. Rio de Janeiro: Forense, 2007.

NETO, Alfredo Sérgio Lazzareschi. Lei das Sociedades por Ações Anotada. $2^{\mathrm{a}}$ ed. São Paulo: Saraiva, 2006.

EIZIRIK, Nelson. Sociedades Anônimas - Jurisprudência. III Tomo. Vol. I. $1^{\text {a }}$ ed. São Paulo: Renovar, 2008. 
BERTOLDI, Marcelo M.; RIBEIRO, Maria Carla Pereira. Curso Avançado de Direito Comercial. $4^{\mathrm{a}}$ ed. São Paulo: Revista dos Tribunais, 2008.

PROENÇA, José Marcelo Martins. Direitos e Deveres dos Acionistas. In: FINKELSTEIN, Maria Eugênia Reis; PROENÇA, José Marcelo Martins (Coord.). Sociedades Anônimas. Série GV Law. São Paulo: Saraiva, 2007.

MARTINS, Fran. Comentários à Lei das Sociedades Anônimas. Tomo I. Vol. II $2^{\mathrm{a}}$ ed. Rio de Janeiro: Forense, 1982.

MÜLLER, Sergio José Dulac. Direitos Essenciais dos Acionistas Interpretação Sistemática da Proteção aos Minoritários. São Paulo: Do Advogado, 2003.

SILVA, Américo Luís Martins da Silva. Sociedades Empresarias. $1^{a}$ ed. Rio de Janeiro: Forense, 2007.

COMETTI, Marcelo Tadeu. A suspensão do direito dos acionistas de participar nos lucros. Disponível em 〈www.saraivajur.com.br $>$. Acesso em 05 out. 2009.

RAMOS, André Luiz Santa Cruz. Curso de Direito Empresarial - o novo regime jurídico-empresarial brasileiro. $3^{\text {a }}$ ed. Salvador: Jus Podivm, 2009.

〈www.cvm.gov.br $>$ 